\title{
Effect of nitrogen and foliar spray of potassium nitrate and calcium nitrate on growth and productivity of yellow sarson (Brassica campestris L. var yellow sarson) crop under irrigated condition
}

\author{
Amrit Raj* and R. B. Mallick \\ Department of Agronomy, University College of Agriculture, Calcutta University, Kolkata - 700019 (West Bengal), \\ INDIA \\ *Corresponding author. E-mail: amritagnm@rediffmail.com \\ Received: June 6, 2016; Revised received: February 13, 2017; Accepted: April 28, 2017
}

\begin{abstract}
A field experiment was conducted during rabi season of 2007-'08 and 2008-'09 to study the effect of calcium nitrate $\left\{\mathrm{Ca}\left(\mathrm{NO}_{3}\right)_{2}\right\}$ and potassium nitrate $\left\{\mathrm{KNO}_{3}\right\}$ at $50 \%$ flowering stage and soil applied nitrogen $\{\mathrm{N}:(0,40$ and $80 \mathrm{~kg} \mathrm{~N} / \mathrm{ha}$ ) $\}_{\text {on }}$ growth, productivity and economics of yellow sarson at farmers field under irrigated old alluvial soil of West Bengal. Highest leaf area index (LAI) values at 40 days of crop age (1.748 and 1.592), dry matter accumulation (1404.3 and $1288.8 \mathrm{gm}^{-2}$ ) at 80 days and crop growth rate (C.G.R) (27.87 and $25.68 \mathrm{~g} \mathrm{~m}^{-2}$ day $^{-1}$ ) in between 40 to 60 days were obtained at Nitrogen application at the rate of $80 \mathrm{~kg} / \mathrm{ha}$ and mixed spray of $0.203 \% \mathrm{Ca}\left(\mathrm{NO}_{3}\right)_{2}+$ $0.25 \% \mathrm{KNO}_{3}$ respectively. Soil application of $80 \mathrm{~kg} \mathrm{~N} / \mathrm{ha}$ along with foliar spray of $0.203 \% \mathrm{Ca}\left(\mathrm{NO}_{3}\right)_{2}+0.25 \%$ $\mathrm{KNO}_{3}$ resulted increase in seed yield $\left(1.68 \mathrm{t} \mathrm{ha}^{-1}\right)$ by $12 \%$ over $80 \mathrm{~kg} \mathrm{~N} /$ ha with only water spray $\left(1.5 \mathrm{t} \mathrm{ha}{ }^{-1}\right)$. Foliar spray of $0.203 \% \mathrm{Ca}\left(\mathrm{NO}_{3}\right)_{2}+0.25 \% \mathrm{KNO}_{3}$ improved the yield components and seed yield over their sole application. Application of $80 \mathrm{~kg} \mathrm{~N} / \mathrm{ha}$ along with $0.203 \% \mathrm{Ca}\left(\mathrm{NO}_{3}\right)_{2}+0.25 \% \mathrm{KNO}_{3}$ at $50 \%$ flowering stage was found to be the most effective in increasing yellow sarson production in old alluvial soil.
\end{abstract}

Keywords: Nitrate salts, Nitrogen, Winter season, Yellow sarson

\section{INTRODUCTION}

Among all the oilseed crops rapeseed and mustard contributed 24.2 and $23.4 \%$ to the total oilseed production and acreage respectively (2014-15) in India. Among different type of rapeseed, yellow sarson is a short duration winter season oilseed crop popularly grown in West Bengal for its higher seed oil content and good quality oil. Most of the cultivated lands of south western part of West Bengal remain fallow after harvest of kharif rice. Most of these land areas can be brought under cultivation during winter after short duration kharif rice with one or two irrigation facilities. Growing short duration winter oilseed crop like yellow sarson with appropriate and proper use of resources along with the use of suitable package of practices could reduce the shortfall of oilseed production. Late application of $\mathrm{N}$ as foliar spray is effective in reducing flower and pod drop in legume and in oilseed Brassicas increasing seed yield (Sarkar and Mallick, 2009).

Nitrogen $(\mathrm{N})$ plays an important role in growth and yield of rapeseed (Khaliq and Cheema, 2005). It also plays important role in respiration, growth and other metabolic processes. Late application of $\mathrm{N}$ is effective in reducing flower and pod drop in legume and in increasing seed yield (Kwiatkowski, 2012). Nitrogen deficiency therefore plays the most important nutri- tional limitation to rapeseed production. Appropriate doses of soil applied nitrogen could boost oilseed production.

Old alluvial soils of south western part of West Bengal are mostly deficient in nitrogen and crops generally show high degree of responses to nitrogen supplementation. At the same time recovery of nitrogen applied to the soil has been reported to be considerably low. In general, poor recovery of applied nitrogen may be attributed to loss due to leaching, run off, denitrification, volatilization, slow dissolution and inter lattice fixation of $\mathrm{NH}_{4}{ }^{+}$ion by clay minerals. These problems finally culminate into an application efficiency of only about $40 \%$ under any soil and cropping conditions (Parr, 1982).

To overcome such problems, a portion of a plants nutritional need can be met by applying soluble fertilizer directly to the foliage. Foliar fertilization can result in rapid nutrient absorption and utilization to correct deficiencies or to merely prevent nutrient shortage during critical periods of growth. Now - a - days, foliar fertilization is widely used practice to correct nutritional deficiencies in plants and has potential advantages over soil application and it mayincrease the efficacy of fertilizer use (Silberbush, 2002). Foliar nutrition with nitrogen $(\mathrm{N})$ at later stage of crop growth delays the synthesis of abscisic acid and promotes cytokinin 
activity and causes high chlorophyll retention and thereby photosynthetic activity in effective leaves for supply of current photosynthates to the grains resulting in higher yield (Sarkar et al., 2007).

Foliar application of nitrate salt has a positive effect on plant metabolism and thus also promotes yields in oilseed Brassica crops (Kwiatkowski, 2012). Foliar application of different nutrients like potassium nitrate $\left(\mathrm{KNO}_{3}\right)$ and calcium nitrate $\mathrm{Ca}\left(\mathrm{NO}_{3}\right)_{2}$ may be beneficial in increasing yield of different crops. The positive effect of spraying these salts may be derived from $\mathrm{NO}_{3}$ - and both counter ions $\left(\mathrm{K}^{+}\right.$and $\left.\mathrm{Ca}^{++}\right)$(Sarkar and Malik, 2001). The beneficial effect of $\mathrm{NO}_{3}{ }^{-}$in delaying synthesis of ascorbic acid and promoting cytokine activity (Sarkar and Pal, 2006) and $\mathrm{K}^{+}$on photosynthesis, carbohydrates distribution and starch synthesis in storage organs are presumed to be responsible for higher grain yield (Imas and Magen, 2007). Potassium (K) has favourable effects on metabolism of nucleic acids, proteins, vitamins and growth substances (Bednarz and Oosterhuis, 1999). Calcium $\left(\mathrm{Ca}^{++}\right)$may substantially increase $\mathrm{N}$ and $\mathrm{P}$ uptake and this may be helpful in promoting root growth (Sarkar and Mallick, 2009). $\mathrm{Ca}^{++}$may result uptake of more soil $\mathrm{N}$ and more assimilation of $\mathrm{NO}_{3}{ }^{-}$in roots and leaves (Sarkar and Pal, 2006). Calcium $\left(\mathrm{Ca}^{++}\right)$cation is a constituent of cell wall and plays role in cellular functions and activity of enzymes (Evangelista et al., 2000).

With these points in view, an experiment has been undertaken to ascertain the response of yellow saron (cultivar: 'B-9') to different concentrations of potassium nitrate $\left(\mathrm{KNO}_{3}\right)$ and calcium nitrate $\left\{\mathrm{Ca}\left(\mathrm{NO}_{3}\right)_{2}\right\}$ salts applied through foliar application at $50 \%$ flowering stage of crop growth and soil applied nitrogen $(\mathrm{N})$ at different three levels $(0,40$ and $80 \mathrm{~kg} \mathrm{~N} / \mathrm{ha})$ under irrigated conditions in farmer's field of Pingla block, Paschim Medinipur, West Bengal.

\section{MATERIALS AND METHODS}

The field experiment was conducted during the winter season of 2007-'08 and 2008-'09 at farmer's field in Paschim Medinipur district of West Bengal, India (22 $14 \mathrm{~N}$ latitude and $87^{\circ} 33^{`} \mathrm{E}$ longitude and approximately $14.11 \mathrm{~m}$ above sea level. Soil was loamy, having $0.39 \%$ organic carbon, $20.4 \mathrm{~kg}$ available $\mathrm{P}_{2} \mathrm{O}_{5} /$ ha (hectare) and $220.12 \mathrm{~kg}$ available $\mathrm{K}_{2} \mathrm{O} /$ ha with $\mathrm{pH}$ 5.31. The seeds of yellow sarson (cultivar 'B-9') were sown after harvest of high yielding rice (cultivar MTU1010). The gross plot size was $5 \mathrm{~m} \times 3 \mathrm{~m}$. The seed yield was computed on the basis of net plot $(4.5 \mathrm{~m} \mathrm{x}$ $2.5 \mathrm{~m}$ ) harvested. The experiment was laid out in factorial randomised block design with three replications. The treatments consisted of soil application of three levels of $\mathrm{N}(0,40$ and $80 \mathrm{~kg} \mathrm{~N} / \mathrm{ha})$ and five levels foliar spray \{water spray, $0.25 \% \mathrm{KNO}_{3}, 0.5 \% \mathrm{KNO}_{3}$, $0.203 \% \mathrm{Ca}\left(\mathrm{NO}_{3}\right)_{2}, 0.406 \% \mathrm{Ca}\left(\mathrm{NO}_{3}\right)_{2}, 0.25 \% \mathrm{KNO}_{3}$ $\left.+0.203 \% \mathrm{Ca}\left(\mathrm{NO}_{3}\right)_{2}\right\}$. Foliar spray of potassium nitrate, calcium nitrate at their respective concentration supplied equal amount of $\mathrm{NO}_{3}^{-}-\mathrm{N}$ (nitrate - nitrogen) to the crop. $\mathrm{KNO}_{3}$ contained $38.7 \% \mathrm{~K}$ and $61.3 \%$ $\mathrm{NO}_{3}$ where as $\mathrm{Ca}\left(\mathrm{NO}_{3}\right)_{2}$ contained $24.4 \% \mathrm{Ca}$ and $75.6 \% \mathrm{NO}_{3}$. After harvest of rice crop, at proper soil moisture level the pre soaked seeds of yellow sarson (cv. B-9) at $5 \mathrm{~kg} /$ ha were sown in line keeping rows 30 $\mathrm{cm}$ apart and plant spacing of $10 \mathrm{~cm}$ in a row was maintained. In both years sowing was done by $25^{\text {th }}$ November after proper soil tilth condition was being achieved.

Basal 2/3 rd nitrogen (doses as per respective treatments), total phosphorus (40kg $\mathrm{P}_{2} \mathrm{O}_{5} / \mathrm{ha}$ ) and potassium $\left(27 \mathrm{~kg} \mathrm{~K} \mathrm{~K}_{2} \mathrm{O} / \mathrm{ha}\right)$ were applied in between rows below the surface soil in bands a day after seed sowing. Remaining $1 / 3 \mathrm{rd}$ dose of nitrogen and potassium (13 $\left.\mathrm{kg} \mathrm{K}_{2} \mathrm{O} / \mathrm{ha}\right)$ were applied at 30 days after sowing.

Table 1. Effect of nitrogen and foliar spray of nitrate salts on growth, physiological parameters, yield components, seed yield and stover yield of yellow sarson (data pooled of 2007-08 and 2008-09).

\begin{tabular}{|c|c|c|c|c|c|c|c|c|c|}
\hline \multirow[t]{2}{*}{ Treatments } & $\begin{array}{c}\text { Plant } \\
\text { height } \\
(\mathrm{cm} .)\end{array}$ & $\begin{array}{l}\text { Dry matter } \\
\text { accumula- } \\
\text { tion }\left(\mathrm{gm}^{-2}\right)\end{array}$ & $\begin{array}{c}\text { Leaf } \\
\text { Area } \\
\text { Index }\end{array}$ & $\begin{array}{l}\text { Crop Growth } \\
\text { Rate }\left(g_{-1}^{-1}\right)\end{array}$ & $\begin{array}{c}\text { Number of } \\
\text { siliquae/ } \\
\text { plant }\end{array}$ & $\begin{array}{c}\text { Number } \\
\text { of seeds/ } \\
\text { siliqua }\end{array}$ & $\begin{array}{c}1000 \\
\text { Seed } \\
\text { weight }\end{array}$ & $\begin{array}{l}\text { Seed } \\
\text { yield }\end{array}$ & $\begin{array}{c}\text { Stover } \\
\text { yield }\end{array}$ \\
\hline & at harvest & 80DAS & 40DAS & 40-60DAS & & & (g) & $\left(\mathrm{t} \mathrm{ha}^{-1}\right)$ & $\left(\mathrm{tha}^{-1}\right)$ \\
\hline \multicolumn{10}{|l|}{$\mathrm{N}(\mathrm{Kg} / \mathrm{ha})$} \\
\hline 0 & 86.62 & 1027.6 & 1.134 & 20.76 & 79.70 & 18.78 & 2.03 & 0.82 & 1.64 \\
\hline 40 & 115.75 & 1230.9 & 1.488 & 24.53 & 91.29 & 20.31 & 2.44 & 1.31 & 2.77 \\
\hline 80 & 135.01 & 1404.3 & 1.748 & 27.87 & 99.25 & 20.91 & 2.56 & 1.56 & 3.56 \\
\hline $\mathrm{CD}(\mathrm{P}=0.05)$ & 0.17 & 2.5 & 0.014 & 0.17 & 1.87 & 0.40 & 0.02 & 0.02 & 0.05 \\
\hline \multicolumn{10}{|l|}{ FOLIAR } \\
\hline WATER SPRAY & 96.01 & 1058.7 & 1.265 & 21.46 & 88.31 & 18.87 & 1.97 & 1.13 & 2.42 \\
\hline $0.25 \% \mathrm{KNO}_{3}$ & 114.69 & 1237.7 & 1.467 & 24.62 & 91.17 & 21.28 & 2.17 & 1.19 & 2.55 \\
\hline $0.5 \% \mathrm{KNO}_{3}$ & 119.74 & 1280.7 & 1.533 & 25.53 & 89.23 & 19.31 & 2.54 & 1.29 & 2.79 \\
\hline $0.203 \% \mathrm{Ca}\left(\mathrm{NO}_{3}\right)_{2}$ & 106.51 & 1205 & 1.424 & 23.98 & 90.27 & 20.86 & 2.17 & 1.16 & 2.49 \\
\hline $0.406 \% \mathrm{Ca}\left(\mathrm{NO}_{3}\right)_{2}$ & 113.9 & 1254.7 & 1.462 & 25.04 & 90.36 & 19.04 & 2.43 & 1.22 & 2.61 \\
\hline $\begin{array}{l}0.25 \% \quad \mathrm{KNO}_{3} \\
0.203 \% \mathrm{Ca}\left(\mathrm{NO}_{3}\right)_{2}\end{array}$ & 123.89 & 1288.8 & 1.592 & 25.68 & 91.12 & 20.66 & 2.77 & 1.38 & 3.08 \\
\hline $\mathrm{CD}(\mathrm{P}=0.05)$ & 0.25 & 3.53 & 0.020 & 0.26 & 2.64 & 0.28 & 0.02 & 0.03 & 0.06 \\
\hline $\begin{array}{l}\text { INTERACTION } \\
(\mathrm{FXN}) \mathrm{CD}(\mathrm{P}=0.05)\end{array}$ & 0.43 & 6.09 & 0.037 & 0.43 & 4.58 & 0.69 & 0.04 & 0.06 & 0.12 \\
\hline
\end{tabular}


Table 2. Effect of nitrogen and foliar spray of nitrate salts on Seed yield (t ha ${ }^{-1}$ ) (pooled of 2007-'08 and 2008-'09) of yellow sarson.

\begin{tabular}{|c|c|c|c|c|c|c|c|}
\hline \multirow[b]{2}{*}{$\mathrm{N}(\mathrm{kg} / \mathrm{ha})$} & \multicolumn{5}{|c|}{ FOLIAR } & \multicolumn{2}{|c|}{ MEAN OF N(t/ha) } \\
\hline & $\begin{array}{l}\text { Water } \\
\text { spray }\end{array}$ & $\begin{array}{l}0.25 \% \\
\mathrm{KNO}_{3}\end{array}$ & $\begin{array}{l}0.5 \% \\
\mathrm{KNO}_{3}\end{array}$ & $\begin{array}{c}0.203 \% \mathrm{Ca} \\
\left(\mathrm{NO}_{3}\right)_{2}\end{array}$ & $\begin{array}{c}0.406 \% \mathrm{Ca} \\
\left(\mathrm{NO}_{3}\right)_{2}\end{array}$ & $0.25 \%$ & $.203 \% \mathrm{Ca}$ \\
\hline 0 & 0.68 & 0.78 & 0.87 & 0.76 & 0.82 & 1.01 & 0.82 \\
\hline 40 & 1.21 & 1.28 & 1.41 & 1.22 & 1.28 & 1.47 & 1.31 \\
\hline 80 & 1.5 & 1.53 & 1.6 & 1.52 & 1.57 & 1.68 & 1.56 \\
\hline MEAN OF FOLIAR & 1.13 & 1.19 & 1.29 & 1.16 & 1.22 & 1.38 & 1.23 \\
\hline C.D. $(\mathrm{P}=0.05)$ & & $\begin{array}{c}\mathrm{N} \\
0.02 \\
\end{array}$ & & & & & \\
\hline
\end{tabular}

Nitrogen, phosphorus and potassium were supplied through urea, single super phosphate and muriate of potash respectively. Dilute solutions of nutrient salt as per treatment were applied at 800 litres of water/ha as a foliar spray during $50 \%$ flowering stage of the crop. Data were recorded on plants from $0.33 \mathrm{~m}^{2}$ area by random sampling using quadrate for yield components, and seed yield from each plot, treatment wise. Two irrigations were applied, one each at flowering and the other at seed filling stage of the crop.

The required quantities of $\mathrm{KNO}_{3}$ and $\mathrm{Ca}\left(\mathrm{NO}_{3}\right)_{2}$ were 2.0 and $1.624 \mathrm{~kg} /$ ha for $0.5 \% \mathrm{KNO}_{3}$ and $0.406 \% \mathrm{Ca}$ $\left(\mathrm{NO}_{3}\right)_{2}$, respectively. For estimation of dry matter accumulation and measurement of leaf area, ten plants in each plot were sampled in periodic interval. The crop was harvested at 90 days after sowing (DAS). Growth analysis was done as per methods laid by Radford (1967). Plant heights were measured with a meter scale from ground level to the tip of the main stem. Dry matter of plants were estimated by weighing all leaves, branches and stems after being dried them in a hot air oven (at $65{ }^{\circ} \mathrm{C}$ to $70{ }^{\circ} \mathrm{C}$ ) till the constant weight were obtained. Plant nitrogen content was estimated by digestion with concentrated $\mathrm{H}_{2} \mathrm{SO}_{4}$ and distillation process (Jackson, 1973), Plant phosphorus and potassium content was estimated by Tri-acid digestion process (Jackson, 1973).Crude oil content in yellow sarson was determined by the Soxhlet method. The economical parameters, like net monetary returns and benefit: cost ratios were worked out by using the prevailing market price of the inputs and produce in the locality. As error variance for growth and yield parameters of respective treatments during two years were found homogenous, pooled analysis of data was done. SPSS version 13 was used for statistical data analysis. Significant differences between the treatments were compared with the critical difference at $( \pm) 5 \%$ probability by least significant difference.

\section{RESULTS AND DISCUSSION}

Effect of nitrogen: Soil application of nitrogen at 80 $\mathrm{kg} / \mathrm{ha}$ recorded higher plant height $(135.01 \mathrm{~cm})$ over 40 $\mathrm{kg} \mathrm{N} / \mathrm{ha}(115.75 \mathrm{~cm})$ and no nitrogen $(86.62 \mathrm{~cm})$ (Table $1)$. The results showed (Table 1) that dry matter accumulation in plants supplied $80 \mathrm{~kg} \mathrm{~N} /$ ha was highest $\left(1404.3 \mathrm{~g} \mathrm{~m}^{-2}\right)$ among soil applied $\mathrm{N}$ doses. Since $\mathrm{N}$ is a major constituent of chlorophyll and protein and its adequate supply through fertilizer encouraged the photosynthesis, thereby resulting in stem elongation and increased dry matter accumulation during the whole growing period (Sarkar and Pal, 2006; Kwiatkowski, 2012). Increase in levels of nitrogen fertilization up to $80 \mathrm{~kg} / \mathrm{ha}$ enhanced leaf area index and crop growth rate during $50 \%$ flowering stage. Application of $80 \mathrm{~kg}$ $\mathrm{N} /$ ha recorded higher leaf area index (1.748) and crop growth rate $\left(27.87 \mathrm{~g} \mathrm{~m}^{-2}\right.$ day $\left.^{-1}\right)$ during peak growth stage which might be accounted for increased leaf number and size and improved vegetative growth of plant (Sarkar et al., 2007). Application of N significantly improved the number of siliquae/ plant, seeds/ siliqua and 1000 seed weight. $80 \mathrm{~kg} \mathrm{~N} /$ ha recorded highest seed yield (1.56 t ha-1) (table -1 and 2) among soil applied different nitrogen doses. This might be due to improvement of yield components of yellow sarson. The data showed increasing dose of $\mathrm{N}$ had reduced seed oil content of yellow sarson. The low oil content under $80 \mathrm{~kg} \mathrm{~N} /$ ha was may be due to more availability of $\mathrm{N}$ which increased proteinous substances in the seed under high $\mathrm{N}$ supply, large proportion of photosynthates may have diverted to protein formation leaving a potential deficiency of carbohydrates, to be degraded to 'acetyl co-enzyme $\mathrm{A}$ ' for the synthesis of fatty acids (Singh et al., 2012).

Effect of foliar spray of nitrate salts: Foliar application of $\mathrm{KNO}_{3}$ and $\mathrm{Ca}\left(\mathrm{NO}_{3}\right)_{2}$ during $50 \%$ flowering stage of yellow sarson improved growth parameters like plant height $(\mathrm{cm})$, dry matter accumulation $\left(\mathrm{gm}^{-2}\right)$, LAI, C.G.R over water spray probably due to overall improvement in overall growth and high production of photosynthates leading to increased availability, absorption and translocation of nutrients. $\mathrm{KNO}_{3}$ was found superior over $\mathrm{Ca}\left(\mathrm{NO}_{3}\right)_{2}$ in terms of growth attributes and yield at both of their respective higher and lower doses. Whereas the foliar application of $0.25 \%$ $\mathrm{KNO}_{3}+0.203 \% \mathrm{Ca}\left(\mathrm{NO}_{3}\right)_{2}$ concentrations mixed spray was found superior over sole application of either salts at their both higher and lower doses. Foliar nutrients also improved yield components (Table 1) and yield (Tables 1 and 2) of yellow sarson than control as on pooled of two years. Spray off $0.25 \% \mathrm{KNO}_{3}$ $+0.203 \% \mathrm{Ca}\left(\mathrm{NO}_{3}\right)_{2}$ to canopy increased seed yield (1.38 t ha-1) of yellow sarson by $22.12 \%$ over water 
Table 3. Effect of Nitrogen and Foliar spray of nitrate salts on nutrient uptake, seed oil content and economics of yellow sarson crop.

\begin{tabular}{|c|c|c|c|c|c|c|c|c|c|c|c|}
\hline \multirow{2}{*}{ Treatments } & \multicolumn{2}{|c|}{$\begin{array}{l}\text { N uptake(kg/ } \\
\text { ha) (pooled) }\end{array}$} & \multicolumn{2}{|c|}{$\begin{array}{l}\text { P uptake(kg/ } \\
\text { ha) (pooled) }\end{array}$} & \multicolumn{2}{|c|}{$\begin{array}{l}\text { K uptake (kg/ } \\
\text { ha) (pooled) }\end{array}$} & \multirow{2}{*}{$\begin{array}{c}\text { seed oil } \\
\text { content }(\%) \\
(p o o l e d) \\
\end{array}$} & \multicolumn{2}{|c|}{ Net return (Rs/ha) } & \multicolumn{2}{|c|}{ Benefit: cost ratio } \\
\hline & Seed & Stover & Seed & Stover & Seed & Stover & & $2007-08$ & 2008-09 & 2007-08 & 2008-09 \\
\hline \multicolumn{12}{|l|}{$\mathrm{N}(\mathrm{Kg} / \mathrm{ha})$} \\
\hline 0 & 25.28 & 35.97 & 8.78 & 6.76 & 16.66 & 57.88 & 37.67 & 23057.5 & 20757.5 & 1.84 & 1.65 \\
\hline 40 & 38.71 & 61.8 & 13.27 & 9.97 & 26.28 & 79.53 & 41.64 & 42241.5 & 42400 & 3.24 & 3.25 \\
\hline 80 & 31 & 82.12 & 13.89 & 12.3 & 31.05 & 96.09 & 40.59 & 51957.5 & 53391 & 3.85 & 3.95 \\
\hline $\mathrm{CD}(\mathrm{P}=0.05)$ & 0.664 & 0.111 & 0.235 & 0.02 & 0.464 & 0.15 & 0.345 & & & & \\
\hline \multicolumn{12}{|l|}{ FOLIAR } \\
\hline WATER SPRAY & 29.55 & 47.35 & 11.19 & 8.12 & 22.8 & 67.52 & 38.92 & 35207.5 & 34457.5 & 2.75 & 2.69 \\
\hline $0.25 \% \mathrm{KNO}_{3}$ & 30.82 & 62.1 & 11.64 & 9.79 & 24 & 79.32 & 39.93 & 37309.3 & 36892.8 & 2.79 & 2.76 \\
\hline $0.5 \% \mathrm{KNO}_{3}$ & 33.49 & 64.1 & 12.61 & 10.34 & 25.95 & 82.19 & 40.39 & 40607 & 40673.5 & 2.92 & 2.92 \\
\hline $0.203 \% \mathrm{Ca}\left(\mathrm{NO}_{3}\right)_{2}$ & 29.96 & 59.26 & 11.33 & 9.34 & 23.39 & 75.4 & 39.39 & 36409.1 & 35842.6 & 2.79 & 2.74 \\
\hline $0.406 \% \mathrm{Ca}\left(\mathrm{NO}_{3}\right)_{2}$ & 31.5 & 62.2 & 11.9 & 10.01 & 24.54 & 79.49 & 39.96 & 38406.6 & 38123.1 & 2.88 & 2.86 \\
\hline \multicolumn{12}{|l|}{$0.25 \% \mathrm{KNO}_{3}+$} \\
\hline $0.203 \% \mathrm{Ca}\left(\mathrm{NO}_{3}\right)_{2}$ & 34.65 & 64.75 & 13.2 & 10.45 & 27.3 & 83.09 & 41.21 & 44642.8 & 45176.3 & 3.28 & 3.32 \\
\hline $\mathrm{CD}(\mathrm{P}=0.05)$ & 0.939 & 0.157 & 0.333 & 0.029 & 0.657 & 0.212 & 0.487 & & & & \\
\hline \multicolumn{12}{|l|}{ INTERACTION } \\
\hline$(\mathrm{FxN}) \mathrm{CD}(\mathrm{P}=0.05)$ & 1.626 & 0.272 & 0.576 & 0.049 & 1.138 & 0.368 & & & & & \\
\hline
\end{tabular}

spray $\left(1.13 \mathrm{t} \mathrm{ha}^{-1}\right)$. Foliar application of nitrate salts at the beginning of reproductive growth of plants involve in number of physiochemical changes which led to change in growth parameters and ultimately increased the yield of the crop. This result confirms the findings of Sarkar and Mallick (2009) in sunflower. Brevadan and Hodges (1973) in corn and in rapeseed (Szewczuk 2003) have also reported similar results. Foliar spray of nitrate salts had significant effects (at 5 $\%$ level) on seed oil content in sunflower (Sarkar et al., 2007). Seed oil content was increased with the increase in the doses of sole spray of either $\mathrm{KNO}_{3}$ or $\mathrm{Ca}\left(\mathrm{NO}_{3}\right)_{2}$ salts. However, maximum oil (41.21\%) (Table 3) content was recorded at foliar spray of mixture salts of $0.25 \% \mathrm{KNO}_{3}$ and $0.203 \% \mathrm{Ca}\left(\mathrm{NO}_{3}\right)_{2}$ possibly due to positive role of potassium and calcium on oil synthesis.

Interaction effect: Interaction between $\mathrm{N}$ and foliar spray of nitrate $\left(\mathrm{NO}_{3}{ }^{-}\right)$salts was significant (at $5 \%$ level) for seed yield of yellow sarson. Application of $80 \mathrm{~kg} \mathrm{~N}$ in combination with mixed spray of $\mathrm{KNO}_{3}$ $(0.25 \%)$ and $\mathrm{Ca}\left(\mathrm{NO}_{3}\right)_{2}(0.203 \%)$ has produced highest significant (at $5 \%$ level) seed yield among other interaction effects between $\mathrm{N}$ and foliar spray of nitrate salts (Table 2).

Uptake of nutrients: Increasing levels of nitrogen up to $80 \mathrm{~kg} /$ ha enhanced seed N, P, K uptake by the crop (Table - 3). Foliar spray of $0.25 \% \mathrm{KNO}_{3}$ and $0.203 \%$ $\mathrm{Ca}\left(\mathrm{NO}_{3}\right)_{2}$ increased uptake of NPK over the control treatment. However, foliar fertilization of $\mathrm{KNO}_{3}$ showed higher uptake of NPK over $\mathrm{Ca}\left(\mathrm{NO}_{3}\right)_{2}$ and control (Szewczuk 2003). The concentrations of $\mathrm{KNO}_{3}$ and $\mathrm{Ca}\left(\mathrm{NO}_{3}\right)_{2}$ applications helped in better NPK uptake possibly because of improved nutritional environment in the rhizosphere and in plant system and consequently greater uptake by the crop. Foliar applied nitrate salts may help plant to pump sucrose through roots that attracts soil microbes and they promote better nutrient uptake by the roots.
Economics: The economics of yellow sarson cultivation was done during both the year (Table 3). The highest benefit: cost ratios (3.85 and 3.95) was obtained due to application of $80 \mathrm{~kg} \mathrm{~N} / \mathrm{ha}$. Foliar nutrition of $0.25 \% \mathrm{KNO}_{3}+0.203 \% \mathrm{Ca}\left(\mathrm{NO}_{3}\right)_{2}$ gave higher net return (Rs 44642.8 and Rs 45176.3) and benefit: cost ratio (3.28 and 3.32) over the sole application of both the salts at their higher and lower doses.

\section{Conclusion}

From the experiment, it was revealed that the effect of foliar spray of $0.25 \% \mathrm{KNO}_{3}+0.203 \% \mathrm{Ca}\left(\mathrm{NO}_{3}\right)_{2}$ at $50 \%$ flowering stage of yellow sarson resulted highest growth attributes like CGR $\left(25.68 \mathrm{~g} \mathrm{~m}^{-2} \mathrm{day}^{-1}\right.$ at 40 60DAS), LAI (1.592, at 40 DAS); yield components \{e.g., number of siliquae/plant (91.12), 1000 seed weight $(2.77 \mathrm{~g})\}$; seed yield $(1.38 \mathrm{t} / \mathrm{ha})$; seed oil content (41.21\%) and net return (Rs 44642.8 and Rs 45176.3). Among soil applied nitrogen, $80 \mathrm{~kg} \mathrm{~N} / \mathrm{ha}$ recorded highest number of siliquae/plant (99.25), 1000 seed weight $(2.56 \mathrm{~g})$, seed yield $\left(1.56 \mathrm{t} \mathrm{ha}^{-1}\right)$, and $40.59 \%$ seed oil content. While interaction between foliar spray of $0.25 \% \mathrm{KNO}_{3}+0.203 \% \mathrm{Ca}\left(\mathrm{NO}_{3}\right)_{2}$ at $50 \%$ flowering stage and $80 \mathrm{~kg} \mathrm{~N} /$ ha produced highest seed yield $\left(1.68 \mathrm{t} \mathrm{ha}^{-1}\right)$ of the crop.Thus, it can be concluded that, foliar spray of $0.25 \% \mathrm{KNO}_{3}+0.203 \% \mathrm{Ca}\left(\mathrm{NO}_{3}\right)_{2}$ at $50 \%$ flowering stage along with $80 \mathrm{~kg} \mathrm{~N} / \mathrm{ha}$ would be judicious practice for realizing the best performances with regard to growth, seed yield and net return of yellow sarson (Brassica campestris L. var yellow sarson) (variety 'B-9') crop in older alluvial soil of West Bengal.

\section{REFERENCES}

Bednarz, C. W. and Oosterhuis, D. M. (1999). Physiological changes associated with potassium deficiency in cotton. J. Plant Nutr., 22: 303-313

Brevadan, E. R. and Hodges, H. F. (1973). Effect of moisture deficits on $\mathrm{C}$ translocation in corn (Zea mays L.). Plant 
Physiology, 52:436-439

Evangelista, R. M., Bosco, A. and Fernandez, M. I. (2000). Influence of the application pre-harvest of the calcium in the poligalacturonase, pectinmetilesterase and $\beta$ galactosidase activity and texture of the mangos 'Tommy Atkins' stored under refrigeration. Ciencia Agrotecnology, 24:174-181

Imas, P. and Magen, H. (2007). Management of potassium nutrition in balanced fertilization for soybean yield and quality - Global perspective. In: Proceedings of Regional Seminar on Recent Advances in Soybean-based cropping system. National Research Centre for Soybean, Indore. 28-29 September, 2007. Pp.1-20

Jackson, M. L. (1973). Soil chemical analysis, Prentice Hall of India Pvt. Ltd., New Delhi. Pp.45-226

Khaliq, A. and Cheema, Z. A. (2005). Influence of irrigation and nitrogen management on some agronomic traits and yield of hybrid sunflower. Int. J. Agric. Bio., 7: 915-919

Kwiatkowski, C. A.(2012). Response of winter rape (brassica napus 1. ssp. oleifera metzg., sinsk) to foliar fertilization and different seeding rates. Acta Agrobotanica 65 (2):161-170.

Parr, J. F. (1982). Toxicology of adjuvants. In Adjuvants and Herbicides. R. H. Hodgson, editor. Weed Science Society of America, Champaign, IL. 93-112

Radford, P. F. (1967).Growth analysis formulae, their uses and abuses. Crop Science, 171-175
Sarkar, R. K. and Malik, G. C. (2001). Effect of foliar spray of potassium nitrate and calcium nitrate on grasspea (Lathyrus sativus L.) grown in rice fallows. Lathyrus Lathyrism Newsletter, 2:(2001)

Sarkar, R. K. and Pal, P. K. (2006). Effect of pre- sowing seed treatment and foliar spray nitrate salts on growth and yield of greengram (Vigna radiata). Indian Journal of Agricultural Sciences, 76 (1): 62-65

Sarkar, R. K., Deb, N. and Parya, M. K. (2007). Effect of seed treatment and foliar nutrition on growth and productivity of spring sunflower (Helianthus annuus). Indian Journal of Agricultural Sciences, 77(3):191-194

Sarkar, R. K. and Mallick, R. B. (2009). Effect of nitrogen,sulphur and foliar spray of nitrate salts on performance of spring sunflower (Helianthus annuus). Indian Journal of Agricultural Sciences, 79 (12): 986-90

Silberbush, M. (2002). Simulation of ion uptake from the soil. In Plant Roots: The Hidden Half, 3rd ed.; Waisel, Y., Eshel, A., and Kafkafi, U. (eds.); Marcel, Dekker: New York, 651-661

Singh, J., Sahay, N., Singh, H. and Bhadauria, H. S. (2012). Nitrogen and sulphur requirement of mustard under different crop sequences. Ann. pl. soil res., 14 (2): 113 115

Szewczuk, C . (2003). Effect of application of chosen foliar fertilizers on winter hardiness and seed yields of winter rape. Acta Agrophys., 85: 289-295 